\title{
Platinum Acetylacetonate-Titanium Dioxide Nanoparticles
}

National Cancer Institute

\section{Source}

National Cancer Institute. Platinum Acetylacetonate-Titanium Dioxide Nanoparticles. NCI

Thesaurus. Code C153425.

A preparation of platinum acetylacetonate supported by sol-gel technology

functionalized titania, with potential antineoplastic activity. Upon intravenous

administration, the platinum moiety forms complexes with nucleophilic groups such as

GC-rich sites in DNA, inducing intrastrand and interstrand DNA cross-links, as well as

DNA-protein cross-links, resulting in apoptosis and cell growth inhibition. Compared to

platinum alone, the nanoparticle formulation allows increased delivery of platinum to the tumor site, thereby increasing efficacy while reducing systemic toxicity. 